\title{
Quality protein intake is inversely related with abdominal fat
}

\author{
Jeremy P Loenneke ${ }^{1 *}$, Jacob M Wilson², Anssi H Manninen³ ${ }^{3}$ Mandy E Wray ${ }^{1}$, Jeremy T Barnes ${ }^{4}$ and \\ Thomas J Pujol ${ }^{4}$
}

\begin{abstract}
Dietary protein intake and specifically the quality of the protein in the diet has become an area of recent interest. This study determined the relationship between the amount of quality protein, carbohydrate, and dietary fat consumed and the amount of times the $10 \mathrm{~g}$ essential amino acid (EAA) threshold was reached at a meal, with percent central abdominal fat (CAF). Quality protein was defined as the ratio of EAA to total dietary protein. Quality protein consumed in a 24-hour period and the amount of times reaching the EAA threshold per day was inversely related to percent CAF, but not for carbohydrate or dietary fat. In conclusion, moderate to strong correlations between variables indicate that quality and distribution of protein may play an important role in regulating CAF, which is a strong independent marker for disease and mortality.
\end{abstract}

\section{Introduction}

Dietary protein intake and specifically the quality of the protein in the diet has become an area of recent interest, particularly when combined with resistance training (for a thorough review the reader is directed to ref. [1]). Quality of protein is defined as the ratio of essential amino acids (EAA) to dietary protein in grams. The dietary reference intake (DRI) includes no specific recommendation regarding the type of dietary protein consumed or distribution of that dietary protein throughout the day. Approximately $10 \mathrm{~g}$ of EAA, at a meal, maximally stimulates muscle protein synthesis (MPS) [2]. EAA intake beyond this level does not appear to result in an additional anabolic response [3].

Studies have demonstrated that the consumption of dietary protein above the DRI has been associated with favorable changes in body composition [4]. Proposed mechanisms include the maintenance or accretion of lean mass and/or increased thermogenesis and satiety [5]. A 5-year prospective study found that protein intake was inversely related to changes in waist circumference [6]. Waist circumference is a surrogate marker for abdominal obesity, and this type of obesity is associated with significant risks of developing type 2 diabetes, coronary artery disease, stroke, and a higher risk of mortality, even after

\footnotetext{
* Correspondence: jploenneke@ou.edu

'Department of Health and Exercise Science, University of Oklahoma,

Norman, Oklahoma, USA

Full list of author information is available at the end of the article
}

adjustments for general obesity [6]. However, the quality of the protein source consumed and the distribution of that protein throughout the day with respect to central abdominal fat (CAF) have not been investigated in free living conditions.

We sought to determine the relationship between the amount of quality protein consumed in 24-hours and the amount of times the $\sim 10 \mathrm{~g}$ EAA threshold was reached at a meal, with respect to percent CAF. This is a secondary analysis using a data set from a previously reported paper on quality protein, overall body composition (lean mass and total body fat), and bone health [7].

\section{Methods}

Twenty-seven healthy males $(\mathrm{n}=12)$ and females $(\mathrm{n}=15)$ $(22 \pm 3$ yrs.; $169.68 \pm 8.20 \mathrm{~cm} ; 71.7 \pm 13.9 \mathrm{~kg} ; 34.2 \pm$ $10.4 \%$ CAF) participated in this cross sectional study which was approved by the university's institutional review board. Subjects self-reported the amount of minutes (min) each week they participated in aerobic $(174 \pm 244 \mathrm{~min})$ and resistance $(93 \pm 106 \mathrm{~min})$ exercise. EAA intake was determined from a 3-day food record, and amino acid profiling for each food was determined using a computer program (Nutrition Data via USDA National Nutrient Database for Standard Reference, Release 22). The daily food records were averaged across the 3-days to give an average representation of their quality protein, carbohydrate, and dietary fat intake. Distribution of quality protein 
was determined using the EAA threshold for a meal, which occurs with approximately $10 \mathrm{~g}$. The amount of times the subject met this threshold throughout the day was determined and averaged across the 3-days to give an average representation of their quality protein distribution.

A total body DXA scan was performed using a GE Lunar Prodigy (GE Healthcare, Pewaukee, WI). CAF which includes intra-abdominal fat plus anterior and posterior subcutaneous fat can be distinguished using DXA by identifying the specific region of interest within the analysis program. The region of interest was determined by a rectangle defined at the upper edge of the second lumbar vertebra extended to the lower edge of the fourth lumbar vertebra. The vertical sides of this area were the continuation of the lateral sides of the rib cage [8]. Prior to the DXA scan subjects were asked to refrain from eating for 2-3 hours and were asked to void immediately prior to their test. Females were required to complete an over the counter early pregnancy test prior to participation.

Data were analyzed using Pearson partial coefficient correlations, controlling for body mass and self-reported aerobic and resistance training minutes per week; with an alpha level of 0.05. Data are presented as \pm SD. Data from males and females were pooled together to increase statistical power and research indicates that skeletal muscle metabolism of protein does not differ by gender in healthy young humans [9]. Furthermore, Glickman et al. [10] found that this method of estimating CAF provides a valid estimate in both males and females.

\section{Results}

Mean values for dietary protein, EAAs, quality protein, and times reaching the EAA threshold have been previously reported $(91 \mathrm{~g} \pm 45 ; 35.9 \mathrm{~g} \pm 19.5 ; 0.38 \pm 0.02$; and $1.4 \pm 0.9$ respectively) [7]. Mean values for carbohydrate and dietary fat intake were $235.3 \pm 85.7 \mathrm{~g}$ and $72.0 \pm 28.6$ g respectively. Quality protein consumed in a 24-hour period was inversely related with percent CAF $(r=-.420, p=$ 0.041 , Figure 1). No associations were found with carbohydrate $(\mathrm{r}=-.198, \mathrm{p}=0.354)$ or dietary fat $(\mathrm{r}=-.196, \mathrm{p}=$ 0.359) with percent CAF. The amount of times reaching the EAA threshold for a meal throughout the day was also inversely related with percent CAF $(r=-.547, \mathrm{p}=0.006$, Figure 2).

\section{Discussion}

Currently, the DRI makes no recommendation with regard to the quality of protein consumed, or the distribution of that protein throughout the day. The data from this study demonstrates that both quality and distribution of dietary protein throughout the day is important. The quality and distribution of protein are of particular interest to those who are energy restricted, who might benefit from the consumption of a higher quality protein source

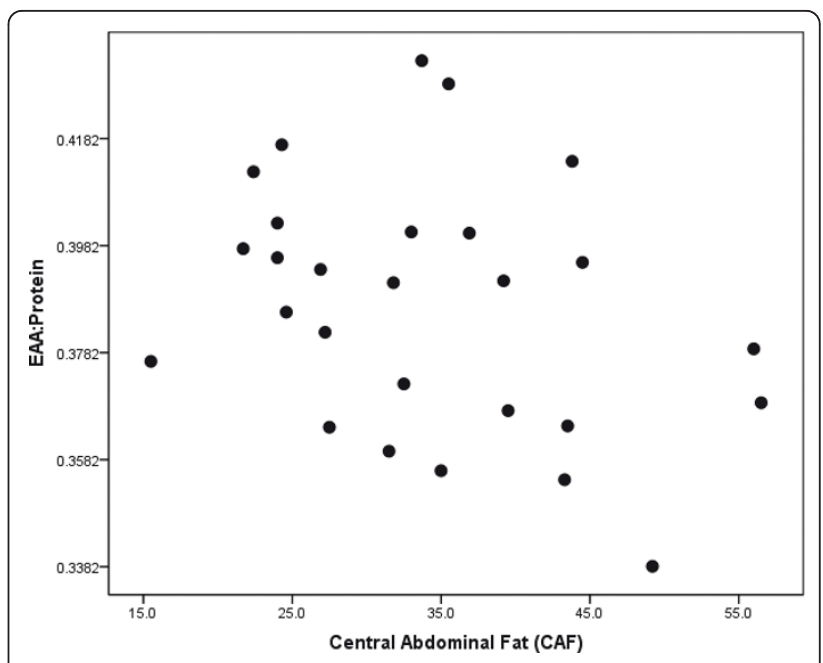

Figure 1 Scatterplot depicting the relationship between quality protein (Essential Amino Acid:Protein) and percent central abdominal fat (CAF).

(e.g. milk, egg, beef), resulting in a higher EAA content per gram of protein. Neither carbohydrate nor dietary fat intake was associated with percent CAF, which confirms previous data, highlighting the importance of protein intake [6].

Previous research has demonstrated a plateauing of muscle contractile protein synthesis following approximately 9-10 g of EAA; meaning dietary intake of EAAs above this threshold does not significantly contribute to the accretion of skeletal muscle [1]. Researchers have postulated [11] and recently shown that a small difference in the quantity of lean mass has a significant effect on resting energy expenditure [12]. Also, the majority of energy used

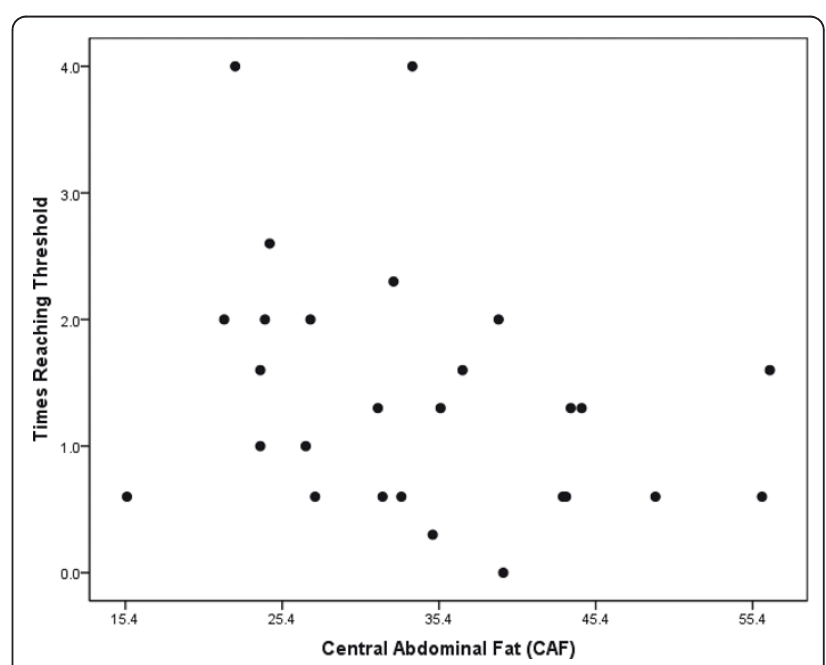

Figure 2 Scatterplot depicting the relationship between times reaching the essential amino acid threshold and percent central abdominal fat (CAF). 
to provide ATP for muscle protein turnover comes from the oxidation of fat, as this is the preferred energy substrate of muscle at rest [13]. Therefore, a focus on maximizing the muscle synthetic response with $\sim 10 \mathrm{~g}$ of EAA may decrease CAF through increased resting energy expenditure from increased lean mass.

In conclusion, moderate to strong correlations between variables indicate that quality and distribution of protein may play an important role in regulating CAF, which is a strong independent marker for disease and mortality. These results warrant further investigation into quality and protein distribution, both of which are currently not covered under the DRI.

\section{Acknowledgements}

This research was not supported by any outside funding.

\author{
Author details \\ ${ }^{1}$ Department of Health and Exercise Science, University of Oklahoma, \\ Norman, Oklahoma, USA. ${ }^{2}$ Department of Health Sciences and Human \\ Performance. University of Tampa, Tampa, Florida, USA. ${ }^{3}$ Manninen \\ Nutraceuticals Oy, Oulu, Finland. ${ }^{4}$ Department of Health, Human \\ Performance, and Recreation. Southeast Missouri State University, Cape \\ Girardeau, Missouri, USA.
}

\section{Authors' contributions}

All authors read and approved the final version of the manuscript. JPL, JTB, and TJP participated in the design and coordination of the study. JPL and JTB were jointly responsible for data collection. JPL, JMW, AHM, and MEW were primarily responsible for writing and statistical analysis.

\section{Competing interests}

The authors declare that they have no competing interests.

Received: 12 December 2011 Accepted: 27 January 2012

Published: 27 January 2012

\section{References}

1. Hulmi JJ, Lockwood CM, Stout JR: Effect of protein/essential amino acids and resistance training on skeletal muscle hypertrophy: A case for whey protein. Nutr Metab (Lond) 2010, 7:51.

2. Cuthbertson D, Smith K, Babraj J, Leese G, Waddell T, Atherton P, Wackerhage $H$, Taylor PM, Rennie MJ: Anabolic signaling deficits underlie amino acid resistance of wasting, aging muscle. FASEB J 2005, 19:422-424.

3. Symons TB, Sheffield-Moore M, Wolfe RR, Paddon-Jones D: A moderate serving of high-quality protein maximally stimulates skeletal muscle protein synthesis in young and elderly subjects. J Am Diet Assoc 2009, 109:1582-1586.

4. Layman DK: Dietary Guidelines should reflect new understandings about adult protein needs. Nutr Metab (Lond) 2009, 6:12.

5. Halton $T L, H u F B$ : The effets of high protein diets on thermogenesis, satiety and weight loss: A critical review. J Am Coll Nutr 2004, 23:373-385.

6. Halkjaer J, Tjonneland A, Thomsen BL, Overvad K, Sorensen TI: Intake of macronutrients as predictors of $5-y$ changes in waist circumference. Am J Clin Nutr 2006, 84:789-797.

7. Loenneke JP, Balapur A, Thrower AD, Syler G, Timlin M, Pujol TJ: Short report: Relationship between quality protein, lean mass and bone health. Ann Nutr Metab 2010, 57:219-220.

8. Kamel EG, McNeill G, Van Wijk MC: Usefulness of anthropometry and DXA in predicting intra-abdominal fat in obese men and women. Obes Res 2000, 8:36-42.

9. Jahn LA, Barrett EJ, Genco ML, Wei L, Spraggin TA, Fryburg DA: Tissue composition affects measures of postabsorptive human skeletal muscle metabolism: comparison across genders. J Clin Endocrinol Metab 1999, 84:1007-1010.
10. Glickman SG, Marn CS, Supiano MA, Dengel DR: Validity and reliability of dual-energy X-ray absorptiometry for the assessment of abdominal adiposity. J Appl Physiol 2004, 97:509-514.

11. Paddon-Jones D, Westman E, Mattes RD, Wolfe RR, Astrup A, WesterterpPlantenga M: Protein, weight management, and satiety. Am J Clin Nutr 2008, 87(suppl):1558S-1561S.

12. Bray GA, Smith SR, de Jonge $L$, Xie H, Rood J, Martin CK, Most M, Brock C, Mancuso S, Redman LM: Effect of dietary protein content on weight gain, energy expenditure, and body composition during overeating: $\mathrm{A}$ randomized controlled trial. JAMA 2012, 307:47-55.

13. Rasmussen BB, Wolfe RR: Regulation of fatty acid oxidation in skeletal muscle. Annu Rev Nutr 1999, 19:463-484.

doi:10.1186/1743-7075-9-5

Cite this article as: Loenneke et al:: Quality protein intake is inversely related with abdominal fat. Nutrition \& Metabolism 2012 9:5.

\section{Submit your next manuscript to BioMed Central and take full advantage of:}

- Convenient online submission

- Thorough peer review

- No space constraints or color figure charges

- Immediate publication on acceptance

- Inclusion in PubMed, CAS, Scopus and Google Scholar

- Research which is freely available for redistribution
C Biomed Central 